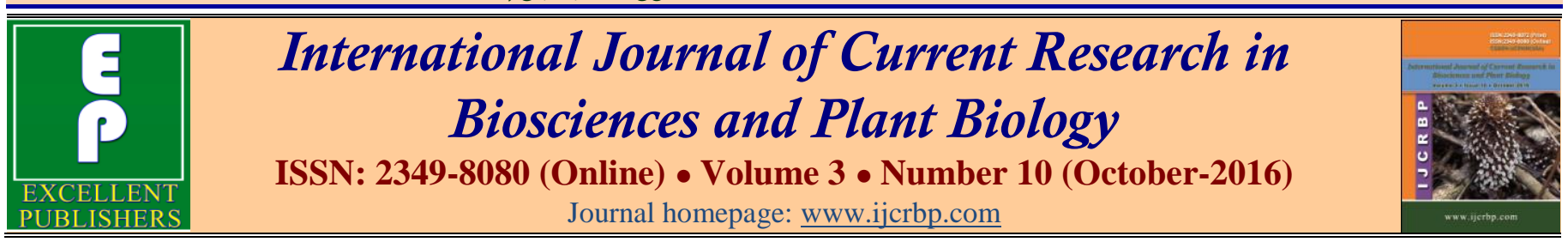

\title{
Flowering Phenology and Reproductive Success of the Orchids of Mt Cameroon in Relation to a Changing Environment
}

\author{
S.E. Essomoํ, B. A. Fonge ${ }^{1 *}$, E.E. Bechem ${ }^{1}$, P. T. Tabot ${ }^{2}$ and B. D. Arrey ${ }^{1}$ \\ ${ }^{1}$ Department of Botany and Plant Physiology, Faculty of Science, University of Buea, P.O. Box 63 Buea, Cameroon \\ ${ }^{2}$ Department of Agriculture, HTTTC Kumba, University of Buea, P.O. Box 249 Kumba, Cameroon
}

*Corresponding author.

\section{A bstract}

A study was conducted in the Mount Cameroon Region from January 2013 to December 2015 on the reproductive biology of orchids. Sixty-nine species of orchids were collected and identified and their flowering times noted. Observations on the flowering phenology of the collected species suggests that most of the orchids flowered during the months of February, March, April, August and September when the rains are intense. Visitors and their rates of visitation of Ansellia africana, Bletilla striata, Bulbophyllum lupulinum, Liparis epiphytica and Polystachya laxiflora were also studied through a "sit and watch" approach. The number of visits varied significantly with the type of visitor. Ants were the only visitor to all 5 orchid species. There was a strong positive correlation between reproductive success and total number of fruits but a weaker correlation between reproductive success and total number of flowers. The species with the highest success rate was Habenaria procera $(86.44 \%)$, while that with the least success rate was Listrostachys pertusa $(01.68 \%)$. The reproductive life cycle of orchids from flowering to dehiscence takes approximately 4 months (flowering \pm 30 days; fruiting \pm 30 and dehiscence (maturing of fruits to busting of capsules) \pm 50 days. Polystachya laxiflora flowered all year round.Fruiting and dehiscence showed no significant trends in all species of orchids. Both factors were dependent on flowering times or respective species. Temperature, rainfall and relative humidity had no significant influence on fruiting and dehiscence of capsules but were important in flowering. The changing climate could therefore significantly sift phenological patterns of the species.
\end{abstract}

\section{Introduction}

Sexual reproduction is just as important for plants as it is for animals when it comes to generating genetic variation (Berenbaum, 1995), but plants must rely on pollen vectors like wind, insects, birds and others to transport their pollen between flowers and between plants. These visitors must be attracted to the same species repeatedly for effective pollination. Such attractions provided by

\section{Article Info}

Accepted: 09 September 2016

Available Online: 06 October 2016

Ke ywords

Mount Cameroon Region

Orchidaceae

Phenology

Reproductive success plants include, but are not limited to, ample nectar or pollen in the right composition, shelter or a place to raise (and feed) young - or by at least looking as if they do (Faegri and van der Pijl, 1971) and floral whorls in the correct colour perception ranges for different pollinators, for example Bees do not see colors at the red end of the visible light spectrum, but they do see colors within the ultraviolet range. Also, many flowers have ultraviolet markings that act as nectar guides that cue insects on 
where to find floral rewards (Barth, 1991; Buchmann and Nabhan, 1996; Proctor et al., 1996).

Knowledge of floral phenology of species is essential in understanding the reproductive patterns and success of these species. The timing of flowering determines levels of possible pollinators and competition among the plants for visits (Waser, 1983; Waser et al., 1996; Caruso, 2000). Thus a strategy deployed by most plants is a shift in flowering time or in changes in floral structure to reduce competition for pollinators (Frankie, 1975; Anderson and Schelfhout, 1980; Medel et al., 2003). In other cases, pollinators must compete with each other, when the floral rewards are in short supply (Thomson, 2004). These adaptations to pollinators are speciesspecific and determine the reproductive success of the species.

Among the most successful of plant groups in extreme environments are orchids. The Orchidaceae (orchid family) is a diverse and widespread family of flowering plants with blooms that are often colourful and fragrant. They are the second largest family of flowering plants after the Asteraceae, with between 21,950 and 26,049 currently accepted species, found in 880 genera (Stevens, 2008; APG, 2009; Focho et al., 2010).

Orchids live in nearly all ecosystems around the world except glaciers, true deserts and open water, although tropical areas especially in Asia, Africa and the Americas are the hotspots of diversity. Most grow as epiphytes on other plants, rocks or static objects for support and derive their nutrients and water from the atmosphere and debris (Simo et al., 2009), however many species grow on the ground in forest or grassland areas. Some are parasites of fungi. Some, such as species in the subfamily Vanilloideae grow as lianas (a woody vine) that can reach sizes up to $20 \mathrm{~m}$ (60 feet) or more in length. On the other hand the tiny Bulbophyllum minutissimum is only 3-4 mm (0.16-0.2 inches) tall (Kew RBG 2013; Williams, 2013). It is unclear whether their morphology determines the reproductive success of the species. However, Orchids generally attract pollinators in mainly three different ways namely 1) offering nectar as a reward to visiting insects, 2) by appearing to offer nectar as a reward (called visual mimicry), or 3) by sexual mimicry in which orchid flowers have evolved to look like, and in some cases smell like, female insects which results in the attracting of male insects of the same (or very closely related) species to land on them and attempt to mate with them. These mechanisms contribute to the reproductive success of the family.
Reproductive success, defined to incorporate inclusive fitness, is the relative production of fertile offsprings by a genotype (Clutton, 1990). The reproductive success of species has hitherto not been assessed for any plant family within in the Mount Cameroon Region. The Orchidaceae, being the second largest family after the Asteraceae (Cable and Cheeck, 1998) and considering its floristic beauty attracts a lot of anthropogenic attention either from photographic tourists or collectors and yet continues to thrive, thus a study of its reproductive success was essential in understanding this hardiness. Also, responses of species' reproductive phenologies to the environmental cues are essential in the current context of climate change. In this light, this research aimed at studying the reproduction biology of some selected species of the Orchidaceae for a period of 3 years to tease out the key aspects of its phenology. The results have interesting implications for conservation of Orchids worldwide.

\section{Materials and methods}

\section{Study site}

This study was carried out in the MCR for a period of 3 years (January 2013 to December 2015). Fig. 1 shows the location of the study site. The Mount Cameroon Region is located in the South West Region of the Republic of Cameroon - West Africa, on the costal belt of the Gulf of Guinea (Focho et al., 2010). The area has a humid tropical climate with climatic pattern sharply modified by the influence of topography (Tchouto, 1996). The mean annual rainfall ranges from $2085 \mathrm{~mm}$ near Ekona to $9086 \mathrm{~mm}$ in Debundscha (Fonge, 2004). The highest monthly rainfall is recorded in July (1072 $\mathrm{mm}$ in Idenau and $284 \mathrm{~mm}$ in Mpundu). Temperature varies more on the west- (between 24 and $28^{\circ} \mathrm{C}$ ) than the east coast where it rarely goes below $27^{\circ} \mathrm{C}$. In the west coast, the lowest temperature is recoded in August, as opposed to September for the east coast (CDC Tiko, 2006). The relative humidity remains at 75 to $80 \%$ throughout the year in the south western side of the mountain, due to marine influence and the incidence of mist and orographic cloud formation. The persistent cloud cover and the mist make this region to receive the lowest amount of annual sunshine in West Africa (Payton, 1993).

Soils are volcanic and relatively fertile but often have poor water retention capacities (Fonge, 2004, Fonge et al., 2005; Focho et al., 2010). The surface of the 
mountain peak is covered by latest lava flows, cinder cones and other pyroclastic materials (Tchouto, 1996).

Vegetation cover is continuous and largely unbroken form sea level to the summit but is characterized by distinct zones. These zones consist of mangroves, the lowland forest (found between 0-800 $\mathrm{m}$ attitude), lowland grass savanna with few trees $(0-800 \mathrm{~m})$, Marantaceae open canopy forest $(500-2000 \mathrm{~m})$, montane rain forest $(800-2500 \mathrm{~m})$, montane grassland (1900-4095 m), recent lava flows with pioneer plants, and plantations. This zonation is determined primarily by altitude but is affected on a smaller scale by edaphic factors (topology, geology and soils) (Fonge, 2004). The abrupt changes in vegetation structure and composition along altitudinal gradient contribute to the mountain's floristic richness. Forest persistence and the presence of high plant communities make this an exceptional biodiversity refuge in Africa (Ndam et al., 2001).

Plant communities in this area are modified by anthropogenic activities such as bush burning for hunting purposes and farming activities, although above $1200 \mathrm{~m}$ the terrain becomes too rough for farming. At lower elevations, the forest has greatly been replaced by fallow lands or organized commercial plantations of mainly oil palms, banana and rubber that are scattered over the southern slopes of the mountain from sea level to $950 \mathrm{~m}$ (Payton, 1993).

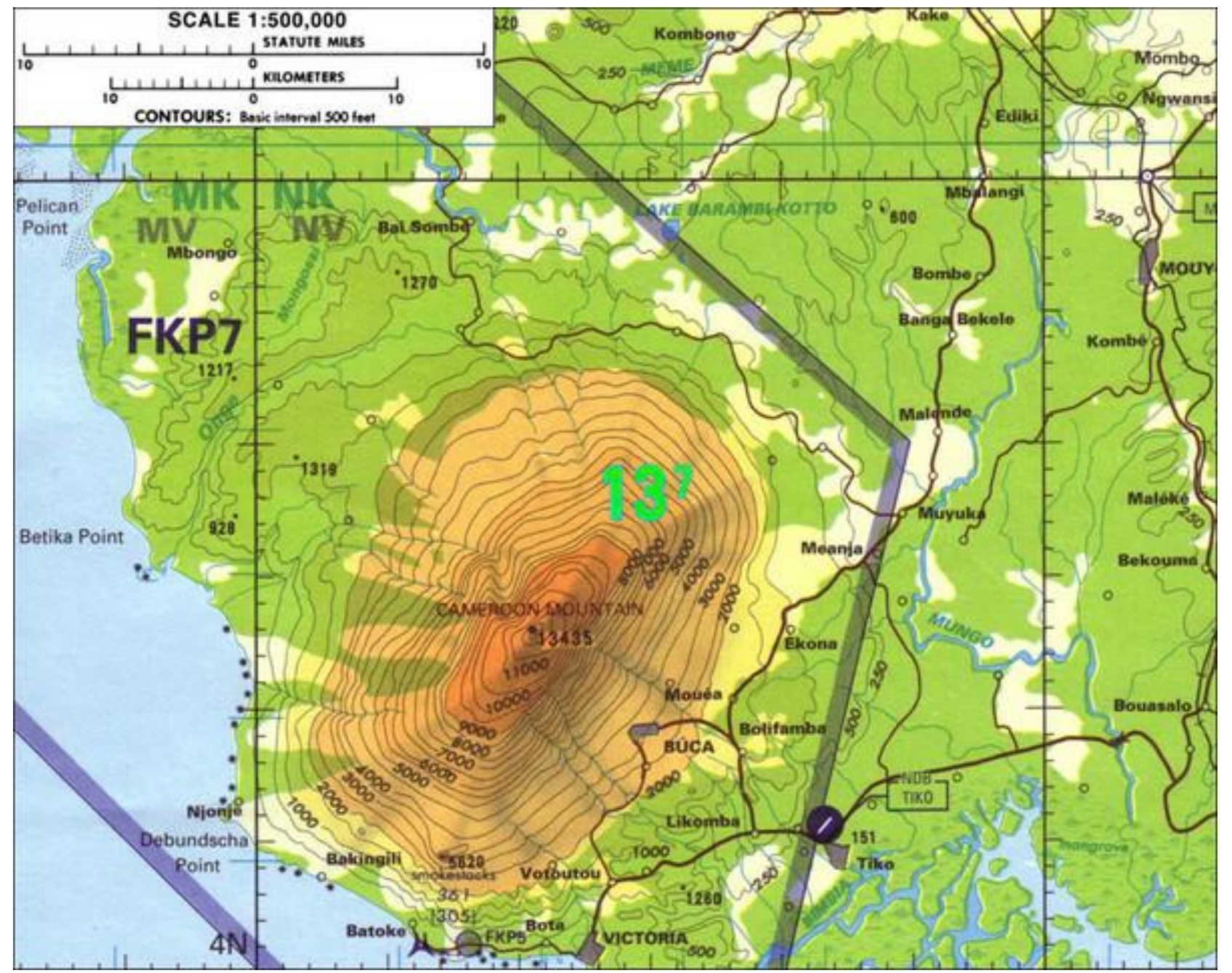

Fig. 1: Topographic map of Mount Cameroon (1:500.000 scale), (Tactical Pilot age Chart L-3A).

\section{Species identification}

Specimens were photographed in situ. Voucher specimens for unidentified species were collected, pressed and dried at $70^{\circ} \mathrm{C}$ for four days to a week. Dried samples and photographs were taken to the Yaounde National Herbarium (YA) and the Limbe Botanic Garden Herbarium (SCA) for identification. 


\section{Phenology study}

Reproductive phenology was studied using the 'sit-andwatch' approach in an orchid garden, as well as parallel observations in the wild. For this, orchid species were collected from the wild and raised in a custom built orchid garden within the study site.

The orchid garden had a dimension of $5 \times 6 \mathrm{~m}$ and was constructed with wood, and roofed with green nets (mesh) for maximum light penetration and sufficient aeration. The sides of the orchid house were not covered so as not to hinder visitors from visiting species found within the garden. The support material was made of wood of 30 inches by 30 and 2 inches thick. Orchids collected were tied to the wood and hung with a cord to the roof such that it was suspended and not touching the ground. Some other species were potted in polythene bags with planting materials made up of a mixture of saw dust and moss in a ratio of 3:1 respectively.

A "Sit-and-Watch" approach was used to identify the various visitors and potential pollinators. These insects were trapped using mesh. Observations were done 3 times daily from 6 am to $9 \mathrm{pm}, 12$ noon to $3 \mathrm{pm}$ and from $6 \mathrm{pm}$ to $8 \mathrm{pm}$ till the flowering periods of respective species were over.

Flowering phenology was observed for the five species in the orchid garden as well as 14 more species in the wild making a total of 19 species. The flowering season was recorded from the onset of flowering through fruit set to dehiscence. Reproductive success was studied for 69 species in the orchid garden, with parallel observations of wild populations. All flowering species in orchid garden were tagged, the number of flowers produced per plant counted and noted. These tagged species were later observed to count the number of fruits that were subsequently produced, so as to estimate the reproductive success of encountered species.

\section{Data analysis}

Key taxonomic features and photographs were used in the description of species. Reproductive success was calculated using an approach used by Singer and Sazima (2001):

Reproductive Success $=\frac{\text { Number of fruits produced }}{\text { Number of flowers produced }}(* 100)$

The MINITAB Version 16 Statistical was used to estimate the correlation between orchids and their pollinators, and reproductive success parameters. Friedman non-parametric two-way ANOVA was done to test the relationships between types of visitors and number of visits to each orchid species. A KruskalWallis analysis was used to test the level of significance between the number of visits to the different orchids. Circular Vector Analysis was conducted in the Oriana Version 4 statistical package to determinate the sequence of flowering, fruiting and dehiscence of respective species over three years. This sequence was matched with the climatic data of the MCR obtained from the C.D.C. meteorological station of Tiko.

\section{Results}

\section{Species studied}

Five species were studied for phenological parameters (Fig. 2). They include Ansellia africana Lindl. 1844, Bulbophyllum lupulinum Lindl. 1862, Polystachya laxiflora Lindl., Liparis nevosa (Thunb.) Lindl. 1830, Bletillas triata (Thunb.) Rchb.f. These species are herein described according to approved taxonomic approaches.

\section{Ansellia africana Lindl. 1844}

Plants usually epiphytic or lithophytic and clustered, swollen into elongate pseudobulbs, to $1 \mathrm{~m}$ tall; leaves spaced along the stem, plicate and lorate. Thin and tough, prominently 3-7 nerved. Inflorescences are terminal, branched, many-flowered; bracts papery and small. Flowers large, showy, and green to yellow and usually prominently spotted brown to maroon. Sepals and petals are similar and usually acute. Lips are 3-lobed.

\section{Bulbophyllum lupulinum Lindl. 1862}

These are small to medium sized epiphytes or lithophytes with ovoid to ellipsoid, slightly compressed, sharply 4 angled pseudobulbs carrying a single to two, lanceolate, to linear-lanceolate, obtusely emarginate, apically slightly flattened leaves. Flower inflorescence with tufted hairs and enveloped below by 10 scarious sheaths and large, scarious, imbricate, triangular, grey -purple with some fine dark hairs, recurved, longer than the flowers floral bracts and carrying distichous, several opening together, not widely opening flowers.

\section{Polystachya laxiflora Lindl.}

These erect epiphytic herb up to $40 \mathrm{~cm}$ long. The stems are clustered on a short rhizome, cylindrical, not swollen 
at the base $2-3 \mathrm{~mm}$ in diameter, 2-3 leaved. Leaves suberect 5.5-21 × 1.8-4.2 cm, narrowly lanceolate, acute, articulated to sheathing leaf bases. Inflorescence (floral axis) shorter than the leaves, simple or with a few short branches up to $2.5 \mathrm{~cm}$ long; pedicle and ovary 5-10 mm long, glabrous. Flowers yellow or cream-coloured the lip slightly darker. Petals 9-11 × 3.5-4.5 mm, oblanceolate. Lip 3-loped in the middle, $11 \times 10 \mathrm{~mm}$ with some clavate hairs on the inner surface. Column short, whitish with a red spot on the anther. Capsules about $3 \mathrm{~cm}$ long (La Croix and Cribb, 1998).

\section{Liparis nevosa (Thunb.) Lindl. 1830}

These are subterranean storage organs (corms) that bear one to three leaves but most common is two. Liparis owes its name to the Greek word for 'greasy' a reference to the shiny appearance of the leave surface. The flowers are small on an erect stalk and are usually drap green, yellow or purple. Sepals and petals have in-rolled edges and a tubular appearance; the narrow petals can appear thread-like. Lateral sepals often are partly fused. The largest element is the lip, frequently notched or pointed at the tip and usually exhibiting way margins. The column is elongated and arching with paired wings near the tip. Some species emit a putrid odour.

\section{Bletilla striata (Thunb.) Rchb.f.}

These are terrestrial, perennial, deciduous orchid of open environments. The grass-like leaves, numbering between 4 and 8 , grow tightly along a central, thick stem to th3e height of $30-50 \mathrm{~cm}$ on average. The leaves are bright green and deeply ribbed, giving the overall impression of a non-flowering plant as that of a typical palm tree seedling. The flower stalk arises out of the top of the leaves at the apex of the main stem and can extend for another $30 \mathrm{~cm}$ or more. The typically pink-purple flowers occur in an alternating pattern along its length and open sequentially, yet several are in flower at any given time. The flower stalks start out in a vertical position, but as more flowers open, they tend to sag down and become horizontal to the ground. The sepals and petals are solid pink-purple and are of similar shape and size. The partially tubular lip is deeply ribbed with a ruffle at the end, and these are often streaked white. The column is long and descending, becoming broader at its tip.
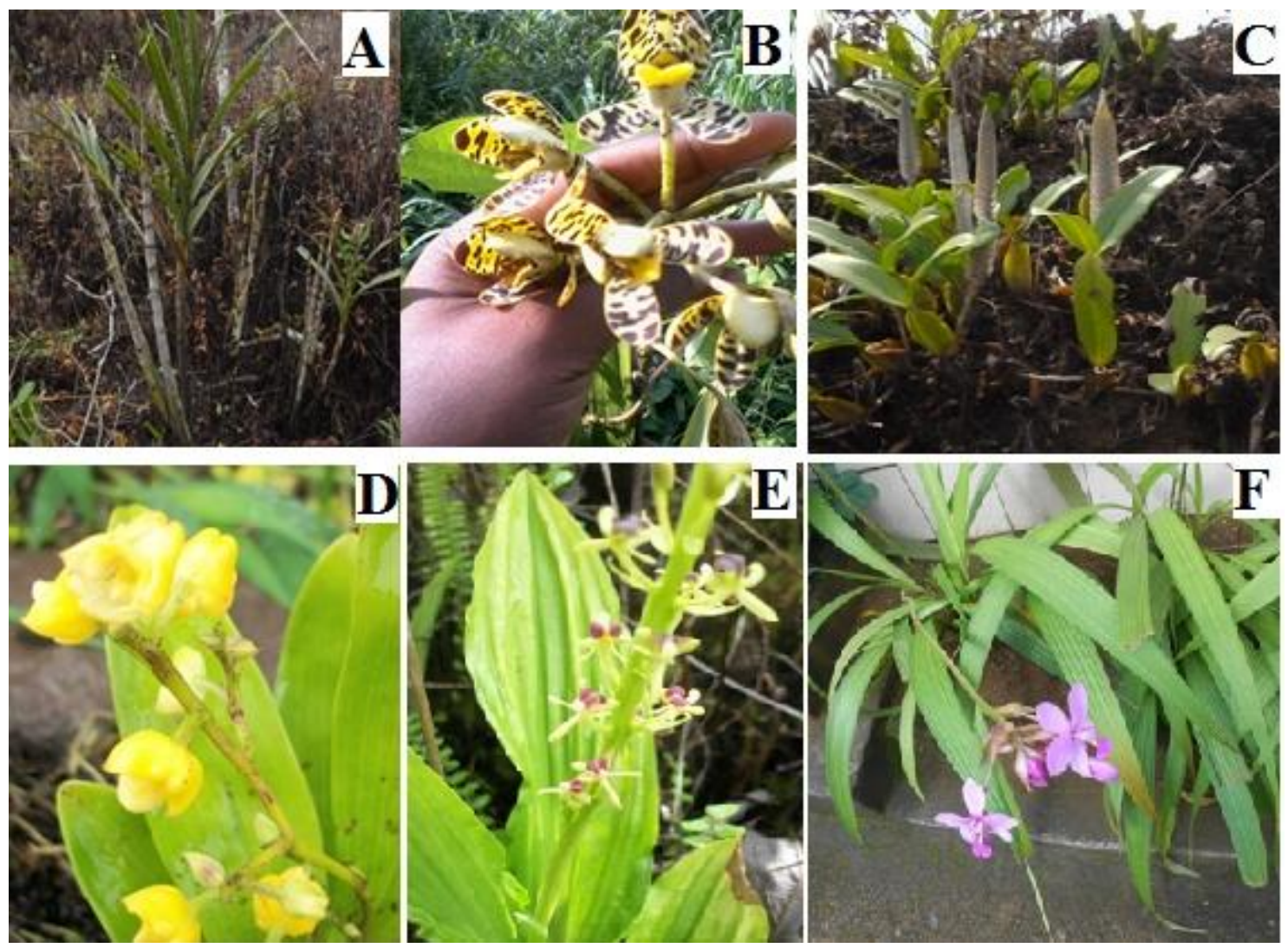

Fig. 2: Species studied for reproductive phenology. $\mathrm{A}$ and $\mathrm{B}=$ Ansellia africana Lindl. 1844; $\mathrm{C}=$ Bulbophyllum lupulinum Lindl. 1862; D = Polystachya laxiflora Lindl.; E = Liparis nevosa (Thunb.) Lindl. 1830; F = Bletilla striata (Thunb.) Rchb.F. 


\section{Phenological studies}

\section{Visitors and potential pollinators}

Fifteen different visitors were observed on the five orchid species, ranging from ants to millipedes and beetles (Fig. 3). Some visitors showed specificity with the orchids, visiting only one species. These include dragonflies, fruit flies, wasp, caterpillars, millipedes and beetles. Ants visited all five species of orchids. The highest number of visits was by houseflies on Bulbophyllum lupulinum (Fig. 3A). A Friedman Test showed that the number of visits to each orchid by the different visitors was not significantly different $(\mathrm{S}=2.96$, $\mathrm{D}=4, p=0.564)$. Kruskal-Wallis test showed that the number of total visits to the orchids did not vary significantly $(\mathrm{H}=3.86, \mathrm{DF}=4, p=0.425)$. The number of visits by specific visitors to each orchid differed significantly $(\mathrm{H}=26.34, \mathrm{DF}=14, p=0.023)$. The number of ants visits was significantly higher than that of dragonflies, wasp, fruit flies, beetles, millipedes and moths (Fig. 3B).

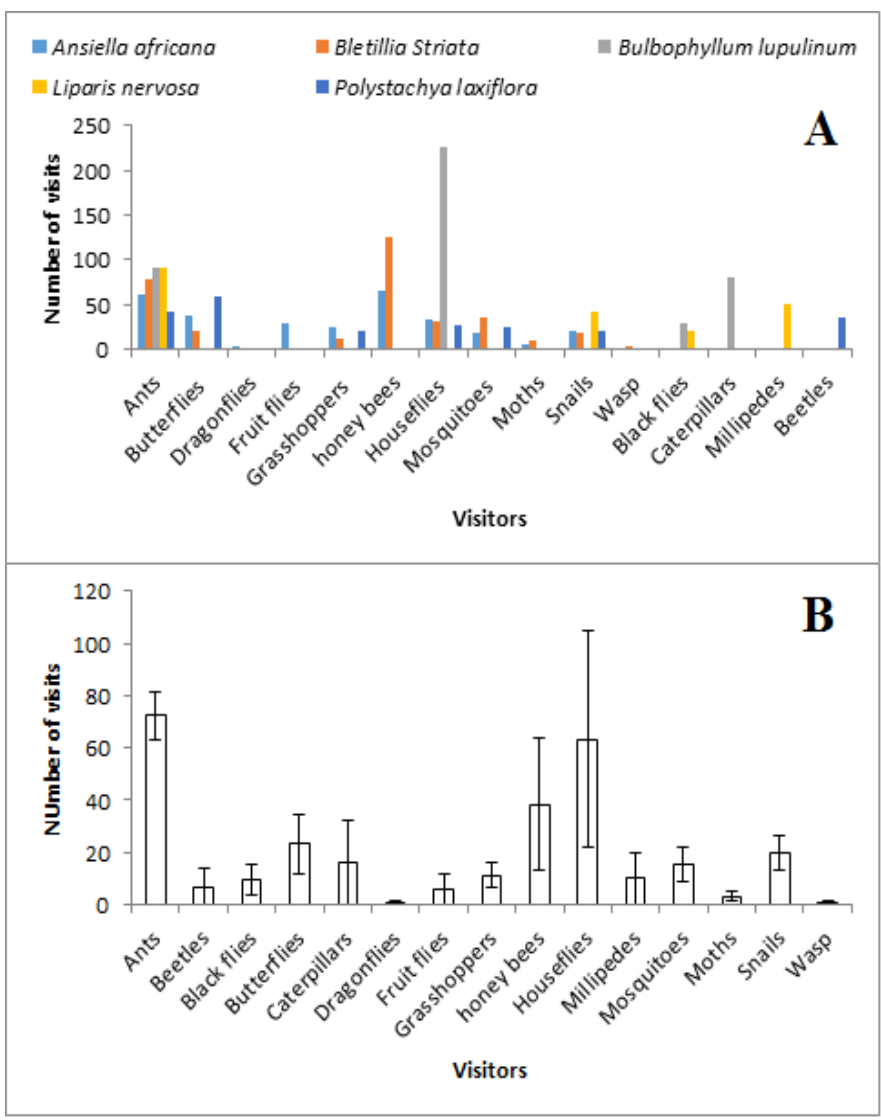

Fig. 3: Frequency of the different visitors to each orchid species studied. $\mathrm{A}=$ number of visits by each visitor with respect to species; $\mathrm{B}=$ mean number of visits per visitor irrespective of orchid species.

\section{Visitors and visiting hours}

Fig. 4 shows the visiting times of the different species. Activities of honey bees were at the peak during the mornings when it was not very hot. They were not found foraging in the afternoons or the evenings during the entire study period. Ants were noted to visit all the time on all species except on Bulbophyllum lupulinum. Beetles were noted only on Polystachya laxiflora in the morning and afternoon. Black flies visited in the morning on Liparis nervosa and Bulbophyllum lupulinum. Butterflies visited Polystachya laxiflora and Bletilla striata in the morning and afternoon and Ansellia africana only in the morning. Caterpillars and flies were noted only on Bulbophyllum lupulinum in the morning and evening respectively. Fruit flies visited only Bletilla striata in the morning and afternoon. Houseflies were recorded all the time on Liparis nervosa and Bulbophyllum lupulinum; in the morning and evening on Polystachya laxiflora and Ansellia africana and did not visit Bletilla striata. Millipede visited only in the evening and only on Liparis nervosa. Moths visited Polystachya laxiflora, B. striata and A. africana in the evening. Wasps were observed in the afternoon on Polystachya laxiflora and Bletilla striata, meanwhile dragon flies were seen only in the evening on Ansellia africana.

\section{Flowering phenology}

Most orchids encountered flowered in the months of February, March, April and September, which are the rainfall months as shown on Fig. 5. None of the orchids flowered in November. The reproductive life cycle of orchids from flowering to dehiscence takes approximately 4 months. Flowering takes \pm 30 days, fruiting (the period where by the flowers turned to fruits completely takes \pm 30 days and dehiscence (the period of maturing of fruits to busting of capsules) takes \pm 50 days. Species that were grown in the orchid garden showed same flowering sequences like their wild counterparts. It was observed that the species which completed their life process (flowering, fruiting and dehiscence) during the rains were found in abundance compared to those that dehisced only after the rainy periods. Ansellia Africana flowered only once (from November to December) during the entire study period.

Polystachya laxiflora flowered all year round, that is individual plants flowered at different times without showing a definite time frame. Its fruiting was observed in September and dehiscence took place in November and December. Similar observations were noted for 
Bletilla striata and Vanda spp., but no fruits were later on produced from flowers.

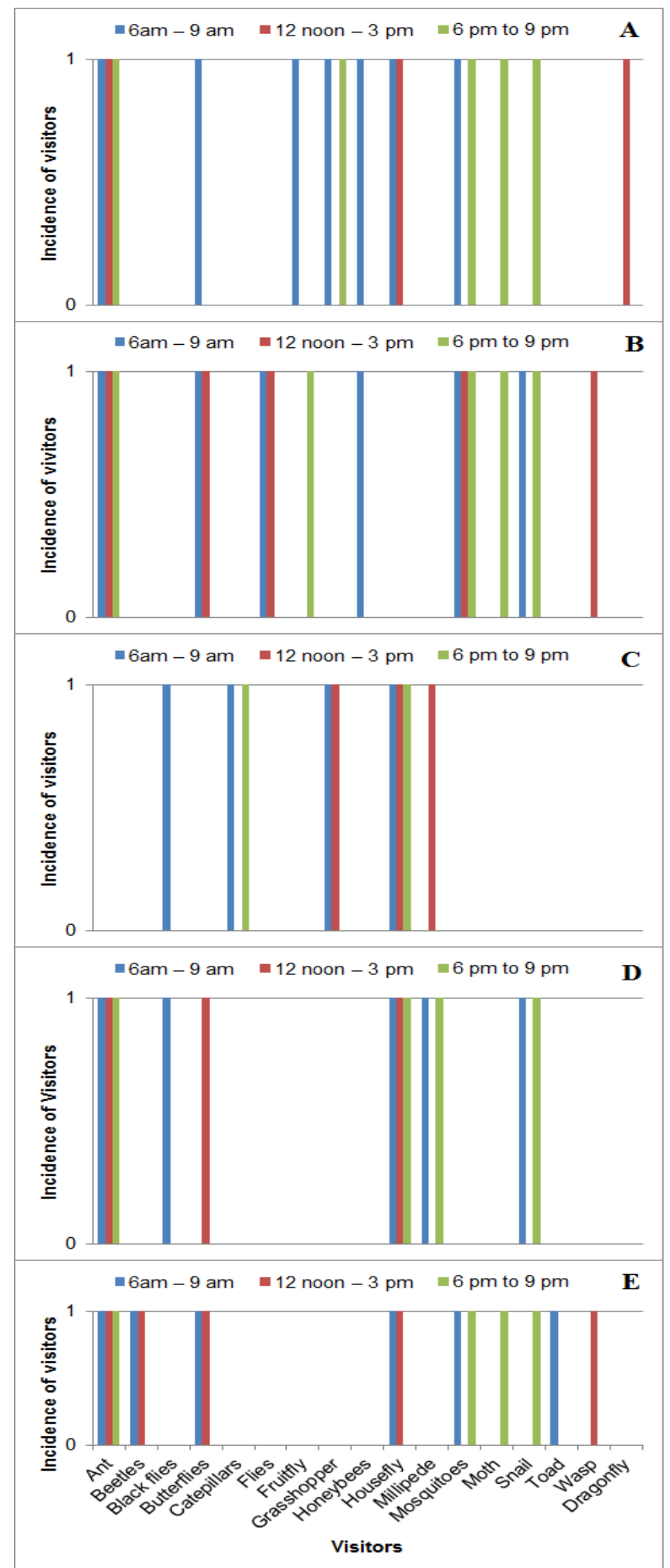

Fig. 4: Visiting times for the different orchid visitors. $\mathrm{A}=$ Ansiella africana; $\mathrm{B}=$ Bletilla striata; $C=$ Bulbophyllum lupulinum; $D=$ Liparis nervosa; $E=$ Polystachya laxiflora.
Table 1 shows Circular Vector statistics for flowering, fruiting and dehiscence of 19 orchid species. The Raleigh p-values less than 0.05 indicate that over time there is a significant shift in the phenophases. From the Table, the angle $(\mu)$ shows the month of either flowering, fruiting or dehiscence with January being $15^{\circ}$ and any additional month is a plus 30 to the $15^{\circ}$; indicating that species with $45^{\circ}$ flowered, fruited or dehisced in February. With time there was a significant shift in flowering for some species including Bulbophyllum porphyrostachys, Angraecum birrimense, Bulbophyllum schiperianum and Calyptrochilum emarginatum (Table 1). Most species that showed a shift in flowering phenology also exhibited a shift in fruiting and dehiscence phenology, for example Liparis nervosa, Polystachya affinis, Polystachya albescence, Polystachya elegance, and Polystachya paniculata (Table 1).

\section{Relationship between phenology and environmental parameters}

The species that were found on the western flank of the mountain included Bulbophyllum porphyrostachys, Bulbophyllum calyptratum, Bulbophyllum schiperianum, Dianphananthe bidens, Liparis nervosa, Polystachya affinis, Bulbophyllum falcatum and Litrostachys pertusa. Those that were found on the eastern flanks were Ansellia africana, Bulbophyllum lupulinum, Calyptrochilum emarginatum, Polystachya albescence and Polystachya elegance. Common species found on both the east and the west coast included Angraecum birrimense, Graphorkis laurida, Habenaria procera and Polystachya paniculata. The flowering periods of similar species on both eastern and western sides of the slopes and those in the orchid garden were similar, although flowers that were found on western flanks were more durable than those on the eastern flanks.

From Table 1, it can be observed that Bulbophyllum lupulinum, Polystachya affinis and Polystachya elegance flowered in February which has a corresponding high temperature, low rainfall and the lowest relative humidity from the climate diagram. Species that took advantage of the highest rainfall, low temperatures and very high relative humidity to kick start flowering were Habenaria procera (June), Angraecum birrimense, Polystachya paniculata and Liparis nervosa which flowered in July and September. Meanwhile Ansellia africana profited from the rains to booster its vegetative growth and later on flowered in September when temperatures are high and rainfall is low, with a corresponding increase in relative humidity. 
Table 1. Flowering, fruiting and dehiscence patterns of orchid species for 3 years.

\begin{tabular}{|c|c|c|c|c|c|c|c|c|c|c|c|c|c|}
\hline \multirow[t]{2}{*}{ Species } & \multirow{2}{*}{$\begin{array}{l}\text { Number } \\
\text { of years }\end{array}$} & \multicolumn{4}{|c|}{ FLOWERING } & \multicolumn{4}{|l|}{ FRUITING } & \multicolumn{4}{|c|}{ DEHISCENCE } \\
\hline & & Angle $(\mu)$ & $\begin{array}{l}\text { Vector } \\
\text { (r) }\end{array}$ & $\begin{array}{l}\text { Rayleigh } \\
\text { test (z) }\end{array}$ & $\begin{array}{l}\text { Rayleigh } \\
\text { test (p) }\end{array}$ & Angle $(\mu)$ & $\begin{array}{l}\text { Vector } \\
\text { (r) }\end{array}$ & $\begin{array}{l}\text { Rayleigh } \\
\text { test }(\mathbf{z})\end{array}$ & $\begin{array}{l}\text { Rayleigh } \\
\text { test }(p)\end{array}$ & Angle $(\mu)$ & $\begin{array}{l}\text { Vector } \\
\text { (r) }\end{array}$ & $\begin{array}{l}\text { Rayleigh } \\
\text { test }(z)\end{array}$ & $\begin{array}{l}\text { Rayleigh } \\
\text { test (p) }\end{array}$ \\
\hline Bulbophyllum porphyrostachys (w) & 03 & $95.104^{\circ}$ & 0.981 & 2.887 & 0.04 & $105^{\circ}$ & 0.921 & 2.546 & 0.067 & $165^{\circ}$ & 0.921 & 2.546 & 0.067 \\
\hline Angraecum birrimense (b) & 03 & $174.896^{\circ}$ & 0.981 & 2.887 & 0.04 & $204.896^{\circ}$ & 0.981 & 2.887 & 0.04 & $264.896^{\circ}$ & 0.981 & 2.887 & 0.04 \\
\hline Ansellia africana (e) & 03 & $255^{\circ}$ & 1 & 2 & 0.137 & $285^{\circ}$ & 1 & 2 & 0.137 & $345^{\circ}$ & 1 & 2 & 0.137 \\
\hline Bulbophyllum calyptratum (w) & 03 & $124.107^{\circ}$ & 0.892 & 2.387 & 0.083 & $154.107^{\circ}$ & 0.892 & 2.387 & 0.083 & $214.107^{\circ}$ & 0.892 & 2.387 & 0.083 \\
\hline Bulbophyllum falcatum (w) & 03 & $285^{\circ}$ & 1 & 3 & 0.33 & $315^{\circ}$ & 1 & 3 & 0.33 & $5.104^{\circ}$ & 0.981 & 2.887 & 0.04 \\
\hline Bulbophyllum lupulinum (e) & 03 & $24.896^{\circ}$ & 0.981 & 2.887 & 0.04 & $54.896^{\circ}$ & 0.981 & 2.887 & 0.04 & $114.896^{\circ}$ & 0.981 & 2.887 & 0.04 \\
\hline Bulbophyllum schiperianum (w) & 03 & $65.104^{\circ}$ & 0.981 & 2.887 & 0.04 & $95.104^{\circ}$ & 0.981 & 2.887 & 0.04 & $155.104^{\circ}$ & 0.981 & 2.887 & 0.04 \\
\hline Calyptrochilum emarginatum (e) & 03 & $84.896^{\circ}$ & 0.981 & 2.887 & 0.04 & $114.896^{\circ}$ & 0.981 & 2.887 & 0.04 & $174.896^{\circ}$ & 0.981 & 2.887 & 0.04 \\
\hline Dianphananthe bidens (w) & 03 & $105^{\circ}$ & 0.921 & 2.546 & 0.067 & $135^{\circ}$ & 0.921 & 2.546 & 0.067 & $184.107^{\circ}$ & 0.892 & 2.387 & 0.083 \\
\hline Graphorkis laurida (b) & ** & ** & ** & ** & $* *$ & ** & ** & ** & ** & ** & ** & ** & ** \\
\hline Habenaria procera $(b)$ & 03 & $165^{\circ}$ & 0.921 & 2.546 & 0.067 & $195^{\circ}$ & 0.921 & 2.546 & 0.067 & $255^{\circ}$ & 0.921 & 2.546 & 0.067 \\
\hline Liparis nervosa (w) & 03 & $245.104^{\circ}$ & 0.981 & 2.887 & 0.04 & $275.104^{\circ}$ & 0.981 & 2.887 & 0.04 & $5.104^{\circ}$ & 0.981 & 2.887 & 0.04 \\
\hline Polystachya affinis (w) & 03 & $45^{\circ}$ & 1 & 3 & 0.03 & $75^{\circ}$ & 1 & 3 & 0.03 & $135^{\circ}$ & 1 & 3 & 0.03 \\
\hline Polystachya albescence (e) & 03 & $125.104^{\circ}$ & 0.981 & 2.887 & 0.04 & $155.104^{\circ}$ & 0.981 & 2.887 & 0.04 & $215.104^{\circ}$ & 0.981 & 2.887 & 0.04 \\
\hline Polystachya elegance (e) & 03 & $45^{\circ}$ & 1 & 3 & 0.033 & $75^{\circ}$ & 1 & 3 & 0.033 & $135^{\circ}$ & 1 & 3 & 0.033 \\
\hline Polystachya paniculata (b) & 03 & $215.104^{\circ}$ & 0.981 & 2.887 & 0.04 & $245.104^{\circ}$ & 0.981 & 2.887 & 0.04 & $305.104^{\circ}$ & 0.981 & 2.887 & 0.04 \\
\hline Litrostachys pertusa (w) & 03 & $264.896^{\circ}$ & 0.981 & 2.887 & 0.04 & $294.896^{\circ}$ & 0.981 & 2.887 & 0.04 & $354.896^{\circ}$ & 0.981 & 2.887 & 0.04 \\
\hline
\end{tabular}

$p$-values greater than 0.05 are not statistically significant; ${ }^{*}=$ insufficient data to run test, $(w)=$ found in the western part of the mountain, $(e)=$ found on the eastern part of the mountain, $(b)=$ found on both western an eastern part of the mountain. 
On the other hand, some other species (Bulbophyllum porphyrostachys, Chameangisem arginatum, Diphananthe bidens and Bulbophyllum calyptratum) start flowering with the unset of high rainfall in April. There was no clear cut boundary as to the period of flowering for Polystachya laxiflora where different individuals were seen flowering at some point in time all year round.

There was no significant trend in the fruiting and dehiscence sequence of species of orchids, because these two were dependent on flowering. It was seen that immediately a species starts to flower, it took a month for the flowers to turn to fruits and it took two months for the fruits to be dehisced for all the orchids. Climate patterns are presented in Fig. 5 for two flanks of the Mt Cameroon where the study was conducted. Temperature, rainfall and relative humidity had no significant influence on fruiting and dehiscence of capsules, but rainfall patterns could explain flowering.

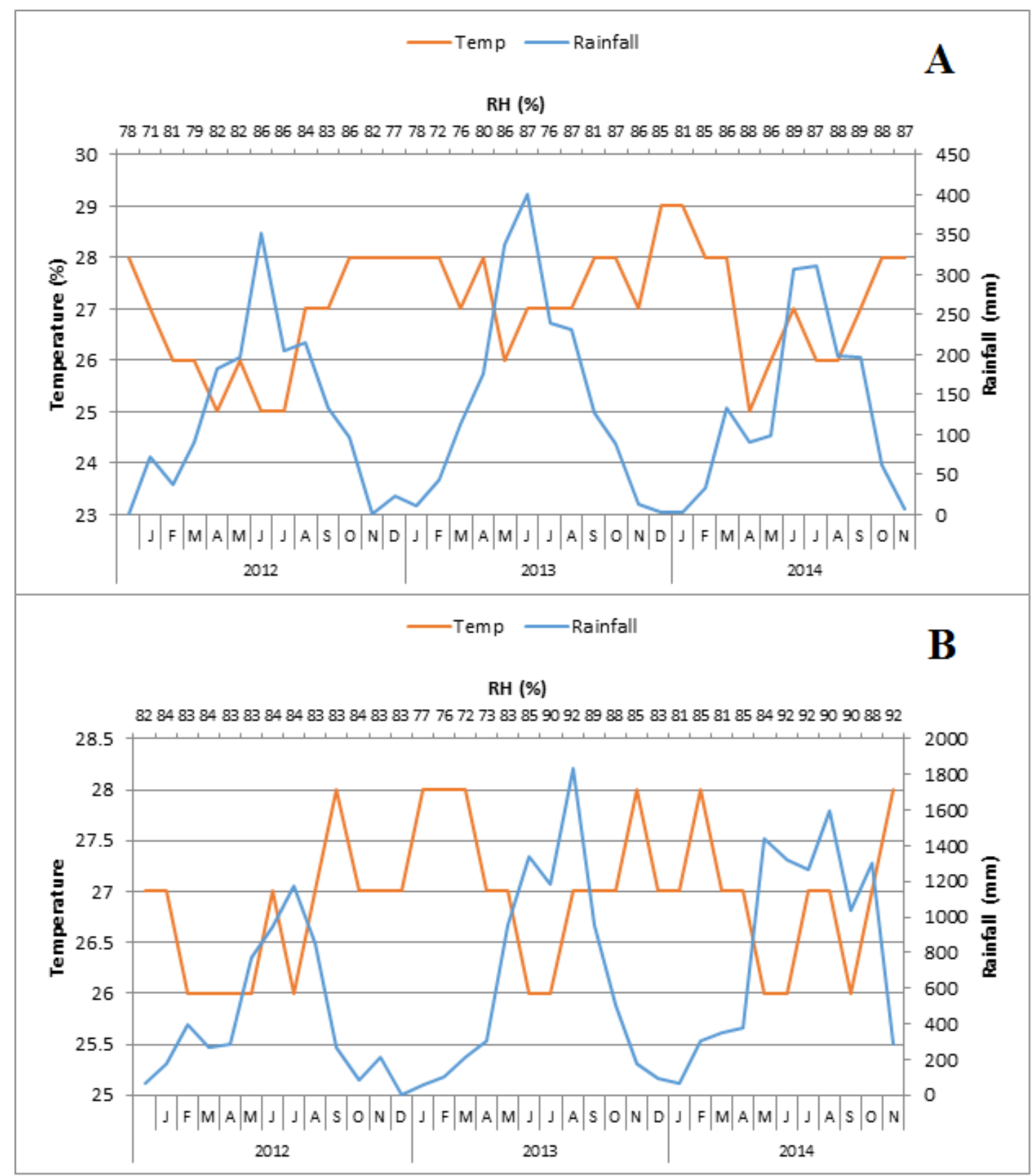

Fig. 5: climate diagrams for the study sites during the study. A = climate data from the Mpundu station on the East flank; B = climate data from the Idenau station on the west flank of the mountain. 


\section{Reproductive success}

Table 2 shows the reproductive success of Orchid species which flowered during the study. Habenaria procera recorded the highest success rate $(86.44 \%)$, closely followed were Liparis nervosa $(78.43 \%)$ and Graphorkis lurida (71.43\%). Five orchid species aborted all flowers. Of those that did not exhibit $100 \%$ flower abortion, the least success rate was observed in Listrostachys pertusa (01.68\%). Members of the genus Bulbophyllum had less than $20 \%$ reproductive success rate, except for B. oreonastes (53\%). Members of the genus Polystachya had considerably high rates of success with $P$. cultriformis, $P$. elegans, $P$. fulvilabia and $P$. paniculata registering rates of more than $60 \%$. All the species that exhibited $100 \%$ flower abortion were cultivated species. There were strong positive correlations between total number of fruits and total number of flowers $(\mathrm{r}=0.729, p=0.000)$, reproductive success and total number of fruits $(r=0.774, p=0.000)$ and a weak correlation between reproductive success and total number of flowers $(r=0.333, p=0.005)$.

Table 2. Reproductive success of 69 orchid species studied in the orchid garden and in the wild.

\begin{tabular}{|c|c|c|c|c|}
\hline $\begin{array}{l}\text { Sl. } \\
\text { No. }\end{array}$ & Species & $\begin{array}{l}\text { Total no. of flowers } \\
\text { counted }\end{array}$ & $\begin{array}{l}\text { Total no. of fruits later } \\
\text { produced }\end{array}$ & Success rate $(\%)$ \\
\hline 1 & Habenaria procera & 59 & 51 & 86.44 \\
\hline 2 & Liparis nervosa & 102 & 80 & 78.43 \\
\hline 4 & Polystachya paniculata & 122 & 86 & 70.49 \\
\hline 5 & Polystachy acultriformis & 67 & 44 & 65.67 \\
\hline 8 & Polystachya elegans & 58 & 35 & 60.34 \\
\hline 9 & Chameangis odoratissimum & 35 & 21 & 60 \\
\hline 10 & Calyptrochilum christyanum & 52 & 29 & 55.77 \\
\hline 11 & Bulbophyllum oreonastes & 30 & 16 & 53 \\
\hline 12 & Polystachya odorata & 34 & 16 & 47.06 \\
\hline 17 & Calyptrochilum emarginatum & 23 & 9 & 39.13 \\
\hline 18 & Polystachya ramulosa & 159 & 60 & 37.73 \\
\hline 19 & Chameangis lanceolata & 38 & 12 & 31.58 \\
\hline 20 & Polystachya albescens & 89 & 26 & 29.21 \\
\hline 21 & Chamaeangis ichneumonea & 18 & 5 & 27.78 \\
\hline 22 & Cyrtorchis arcuata & 20 & 5 & 25 \\
\hline 23 & Polystachya supfiana & 4 & 1 & 25 \\
\hline 24 & Ansellia africana & 18 & 4 & 22.22 \\
\hline 25 & Angraecum augustipetallum & 5 & 1 & 20 \\
\hline 26 & Bolusiella fractiflexa & 5 & 1 & 20 \\
\hline 27 & Bulbophyllum intertextum & 26 & 5 & 19.23 \\
\hline 35 & Solenangis clavatum & 22 & 3 & 13.64 \\
\hline 36 & Polystachya caloglossa & 15 & 2 & 13.33 \\
\hline 37 & Angraecum distichum & 8 & 1 & 12.5 \\
\hline 38 & Bulbophyllum barbigerum & 16 & 2 & 12.5 \\
\hline 39 & Rhipidoglossum rutilum & 48 & 6 & 12.5 \\
\hline 40 & Plectrelminthus caudatus & 25 & 3 & 12 \\
\hline 41 & Polystachya bamendae & 9 & 1 & 11.11 \\
\hline
\end{tabular}




\begin{tabular}{lllll}
\hline Sl. & Species & $\begin{array}{l}\text { Total no. of flowers } \\
\text { counted }\end{array}$ & $\begin{array}{l}\text { Total no. of fruits later } \\
\text { produced }\end{array}$ & Success rate (\%) \\
\hline 42 & Polystachya letouzeyana & 9 & 1 & 11.11 \\
43 & Angraecum bancoense & 10 & 1 & 10 \\
44 & Polystachya concreta & 10 & 1 & 10 \\
45 & Bulbophyllum fuscum & 13 & 1 & 7.69 \\
46 & Bulbophyllum scaberulum & 28 & 2 & 7.14 \\
47 & Bulbophyllum bifarium & 31 & 2 & 6.45 \\
48 & Bulbophyllum porphyrostachys & 46 & 3 & 6.38 \\
49 & Bulbophyllum sandersonii & 16 & 1 & 6.25 \\
50 & Polystachya bifida & 48 & 3 & 6.25 \\
51 & Bulbophyllum pumilum & 18 & 1 & 5.56 \\
52 & Tridactyle tridactylites & 18 & 1 & 5.56 \\
53 & Bulbophyllum resupinatum & 37 & 2 & 5.41 \\
54 & Bulbophyllum falcatum & 56 & 3 & 5.36 \\
55 & Ancistrorhynchus capitatus & 40 & 2 & 5 \\
56 & Polystachya laxiflora & 41 & 2 & 4.88 \\
57 & Bulbophyllum buntingii & 21 & 1 & 4.76 \\
58 & Liparis epiphytica & 46 & 2 & 4.35 \\
59 & Bulbophyllum acutibracteatum & 23 & 1 & 4.34 \\
60 & Bulbophyllum pumilum & 26 & 1 & 3.85 \\
61 & Bulbophyllum melinostachyum & 27 & 1 & 3.7 \\
62 & Bulbophyllum josephii & 33 & 1 & 3.03 \\
63 & Bulbophyllum lupulinum & 69 & 2 & 2.99 \\
64 & Listrostachys pertusa & 119 & 2 & 1.68 \\
65 & Bletilla striata & 27 & 0 & 0 \\
66 & Bletilla sp. & 13 & 0 & 0 \\
67 & Vanda Miss Joaqium & 13 & 0 & 0 \\
68 & Vanda sp1 & 37 & & 0 \\
69 & Vanda sp2 & 21 & 0 & \\
\hline
\end{tabular}

\section{Discussion}

The objectives of this research were to study the reproduction biology of some selected species of the Orchidaceae for a period of 3 years to tease out the key aspects of its phenology. The results show distinct shifts in flowering phenology which could partly be explained by environmental parameters, and pollinator populations that are possibly explained by flower adaptations. These results are explained in this section.

\section{Species adaptations to visitation}

A majority of orchids in the MCR flower during the month of February, March, April, August and September. For better growth, blooming and survival, orchid flowers have to be under less sunlight intensity during the morning hours and under diffuse light/shady atmosphere during the rest of the day. Bees, mosquitoes, flies, moths, butterflies, beetles and ants were found to be responsible for orchid pollination but their visits were infrequent. Similar observations were made by Parra-Tabla and Vargas (2004) and Bhattacharjee and Dutta (2010).
Bee pollination has been reported in Ansellia africana in Kenya (Stewart and Campbell, 1996), yet they equally had a great number of ant's visitations at all periods of the day. This species flowered between the months of November to January, during the very dry and hot periods of the year. Similar observations were equally reported by Dino (2009). The behavioral pattern of ants on Ansellia africana is typical of foragers. It used the species as a nesting site, benefiting from extra-floral rewards. Yet on the other hand these ants could also affect pollination because they parade on the inflorescence, flower to flower. The fruity fragrance of the flowers equally attracted the bees, which has been documented by several authors (Dressler, 1981; Stewart and Campbell, 1996; Dino, 2009) as being the most efficient pollinator of Ansellia africana.

According to Miesel et al. (2014), Liparis are pollinated primarily by mosquitoes and flies, attracted by their unpleasant odour. Compared with bees however, flies are unreliable pollinators. Whereas bees move efficiently from one flower to another collecting and transporting 
food, flies move haphazardly, often visiting the same flower again and again. Perhaps because of this wayward behavior, many Liparis species are capable of selffertilization. Studies of Liparis loeselii, a European and North American species revealed that rainfall would induce self-pollination. Raindrops strike the column loosing pollen masses that are washed into the stigmatic area, thus effecting pollination. This could probably be the case with Liparis nervosa in the current study, which flowered only in September to take advantage of heavy rains with large droplets to effect pollination. Because fly activities are low during heavy rains, the adaptation may improve reproductive success in particularly wet habitats, as was the case with $L$. nervosa in the current study with a reproductive success rate of $78.43 \%$.

In a study carried out by Chung and Chung (2005) on the pollination biology and breeding systems of Bletilla striata, they realized that honey bee Apis mellifera were observed frequenting the flowers. However, they equally realized that a great increase in fruit set was achieved by hand pollination: the percentage of fruit set through artificial self-pollination and geitonogamous pollination were close to $90 \%$, indicating that $B$. striata is selfcompatible. Agamospermy and spontaneous autogamy (automatic self-pollination) were not detected in this study. This indicates that pollination vectors are essential for achieving fruit set in natural populations. Pollination of Bletilla species in the current study could also be accounted for by honey bee which was the most frequent visitor, as well as other insects.

Naoto (1995) showed that Bletilla striata is pollinated by 26 species of insects belonging to Hymenoptera, Diptera and Lepidoptera, although the flower did not offer food rewards of any kind. Among the candidates for pollination were seven species of aculeate Hymenoptera with a body size that well fitted the space in between the column and labellum. The most effective candidate was the male of the longhorn bee Tetralonia nipponensis, because they were the most abundant visitors and carried out legitimate intrafloral behavior. The female of Tetralonia nipponensis and the other six species also contributed to promote out-crossing, but to a lesser extent than the male Tetralonia nipponensis, since they occasionally exhibited illegitimate intrafloral behaviors for pollination and also, their flower visitation rate was lower.

The carrion-smelling flowers of Bulbophyllum porphyrostachys were visited by many flies. Close observation of the flowers showed the lip with shiny oily substances which were constantly probed by the visiting flies and black flies. This oily substance may possibly be the floral reward as food to the flies; but further investigation is necessary to determine the type of substance and the benefits derived by insects upon consumption. The mechanisms with which the flies work in this species is similar to many Bulbophyllum, in which the flowers have a 'see-saw' lip. A fly of the right size and weight that moves forward to the base of the lip while probing on the median groves will be trapped between the lip and column when the lip flips over due to an imbalance. A temporarily trapped and struggling fly will have the pollinia adhere to its dorsum upon freeing itself (Tan and Nishida 2000, 2007). Flies that carry the pollinia will pollinate the flowers if the same scenario is repeated.

\section{Flowering Phenology and the environment}

Flowering phenology is a critical reproductive trait of plants (Bronstein et al., 1990). Flowers provide important food resources for pollinators and other visitors. Environmental cues that initiate onset of flowering include photoperiod, temperature and precipitation. Once flowering has been initiated, the amount of precipitation over the growing season may affect the number of flowers and the duration of flowering for any given species (Inouye, 2002). Environmental change affects the long term survivability and evolutionary potential of pollination as there were fluctuations in the rainfall and temperature pattern within the MCR during the period under review. Orchids are peculiar for specific habitat requirements, in the absence of which there would be rarity (Cribb et al., 2003). Increase of temperature during the rainy season may hasten flowering of orchids. As majority of orchids pollinators are insects, the unusual flowering patterns result in irregular pollinator visits which in turn decrease orchid population.

\section{Reproductive success}

There were significant variations in reproductive success for encountered species within the Mount Cameroon Region. Low success rate in some species could partly be attributed to predation. Flowers of some species like Bulbophyllum porphyrostachys and Polystachya laxiflora were constantly being predated upon by caterpillars and beetles respectively. Some visitors caused devastating effects on the flowers and entire plants. When the floral parts are chewed up by visitors, such flowers hardly turn into fruits, leading to low success rates. 
Climatic conditions also determine reproductive success. Elevated temperatures are known to affect the physiology of flowering plants in a number of ways resulting in altered production of flowers, nectar and pollen (Koti et al., 2005; Petanidou and Smets, 1995; Saavedra et al., 2003) which may equally have an effect on the reproductive success of species.

Studies carried out by Yuan et al. (2009) revealed that hotter temperatures might increase emission and/or volatility of organic compounds produced by flowers. This modification in floral odour and rewards could affect how likely insects are to visit certain flowers and the benefits they accrue. Altered floral scents emission or volatilization at higher temperatures could affect the detectability of flowers, particularly for pollinating insects. Certainly, altered nectar production and composition could have both immediate effects on pollination activity and energetics (Kudo and Harder, 2005) and longer term consequences for pollinator fitness (Burkle and Irwin, 2009). Similarly, decreased pollen production is likely to affect the reproductive success of many bees, which may need to collect pollen from a large number of plants to successfully rear their offsprings (Muller et al., 2006). To crown this, no fruit set can be produced without prior pollination.

\section{Conclusion}

The success rate of any plant species depends on the movement of pollen from the anthers to the stigma of flowering plants. If there is no pollination, there will eventually be no production of fruit. In this study we found that the hybrids and the cultivated Bletilla striata which received large number of visitors to their flowers exhibited $100 \%$ abortion, and further studies need to be carried out to determine the cause of abortion of flowers. The pheno-phases of species were seen to be determined to a large extent by climatic factors, but the fruiting and dehiscence proceeded flowering with no alteration.

The current global warming has a great impact on phenology of plants and pollinators, especially with the orchids which are key species in forest ecosystem. Changes in species range and tropic relationships in relation to climate warming affect their interactions. Orchid pollination systems evolved mainly in response to competition for pollinators (Benzing and Atwoodm, 1984) in a condition were pollinators are not frequent for pollination (Darwin, 1885). Thus the shifts in phenophases for species like Bulbophyllum porphyrostachys, Angraecum birrimense, Bulbophyllum schiperianum and Calyptrochilum emarginatum observed in the current study could be explained in part by this changing climate, but the levels of success in most orchid species studied are testament to the resilience of members of this family in the face of both changing abiotic and anthropogenic dynamics.

\section{Conflict of interest statement}

Authors declare that they have no conflict of interest.

\section{References}

Anderson, R.C, Schelfhout, S., 1980. Phenological patterns among tall grass prairie plants and their implications for pollinator competition. American Midland Naturalist 104, 253-263.

Angiosperm Phylogeny Group (APG), 2009. An update of the Angiosperm Phylogeny Group classification for the orders and families of flowering plants: APG III. Bot. J. Linn. Soc. 161 (2), 105-121.

Barth, F.G., 1991. Insects and Flowers: The Biology of a Partnership. Princeton University Press, New Jersey. 408p.

Benzing, D.H., Atwood, Jr. J.T., 1984. Orchidaceae: ancestral habitats and current status in forest canopies. Syst. Bot. 9, 155-165.

Berenbaum, M., 1995. Bugs in the System: Insects and Their Impact on Human Affairs. Helix Books, Addison Wesley Publishing Company.

Bhattacharjee, B., Dutta, B.K., 2010. Flowering phenology on the orchids of Barak Valley, Assam, India. Biol. Environ. Sci. 6(1), 66-70.

Bronstein, J.L., P.H., Gouyon, C., Gliddon, G., Kjellberg, G., Michaloud, 1990. The ecological consequences of flowering asynchrony in monoecious figs: A simulation study. Ecology. 71, 2145-2156.

Buchmann, S.L., Nabhan, G.P., 1996. The Forgotten Pollinators.Island Press, Washington, D.C. 292p.

Burkle, L.A., Irwin, R., 2009. Nectar limits larval growth of solitary bees (Hymenoptera: Magashilidae). Environ. Entomol. 38, 1293-1300.

Cable, S., Cheek, M., 1998. The Plants of Mount Cameroon: A Conservation Checklist. Royal Botanic Gardens, Kew. 112p.

Caruso, C.M., 2000. Competition for pollination influences selection on floral traits of Ipomopsis aggregata. Evolution. 54, 1546-1557.

CDC Tiko, 2006. Cameroon Development Corporation climatic data. Meteorological station Tiko, Cameroon.

Chung, M.Y., Chung, M.G., 2005.Pollination biology and breeding systems in the terrestrial orchid Bletilla striata. Plant Syst. Evol. 252(1), 1-9.

Clutton, B.T.H., 1990. Reproductive Success: Studies of Individual Variation in Contrasting Breeding Systems. University of Chicago Press. 
Cribb, P.J., Kell, S.P., Dixon, K.W., Barrett, R.L., 2003. Orchid conservation: a global perspective. In: Orchid Conservation. Natural History Publication, Kota Kinabulu, Sabah. pp.1-24.

Darwin, C., 1885. The Various Contrivances by which Orchids are Fertilized by Insects. $2^{\text {nd }}$ Edn. Murray, London.

Dino, J.M., 2009. Pollination and facultative ant-association in the African leopard orchid Ansellia. J. East Afr. Nat. Hist. 98(1), 67-77.

Dressler, W., 1998. Preference vs strict universals in morphology: word-based rules. In: Theoretical Morphology (Eds.: Hammond, M., Noonan, M.). Academic Press, New York.

Faegri, K., Van der Pijl, L., 1971. The Principles of Pollination Biology. Pergamon Press, New York. 281p.

Focho, D.A., Fonge, B.A., Fongod, A.G.N., Essomo, S.E., 2010. A study of the distribution and diversity of the Orchidaceae on some selected lava flows of Mount Cameroon. J. Environ. Sci. Technol. 4(5), 263-273.

Fonge, B.A., 2004. Plant successional trends on some selected lava flows of Mount Cameroon. Ph.D. thesis. University of Buea. 249p.

Fonge, B.A., Yinda, G.S., Focho, D.A., Fongod, A.G.N., Bussmann, R.W., 2005. Vegetation and soil status of an 80 year old lava flow of Mt. Cameroon, West Africa. Lyonia. 8(1), 17-39.

Frankie, G.W., 1975. Tropical forest phenology and pollinator plant coevolution. In: L. E. Gilbert and P. H. Raven, eds, Coevolution of Animals and Plants. University of Texas Press, Austin, Texas, U.S.A. pp.192-209.

Inouye, D.W., 2002. Environmental influences on the phenology and abundance of flowering by Androsacesepten trionalis (Primulaceae). Am. J. Bot. 90(6), 905-910.

Kew Royal Botanic Gardens, 2013. The orchid family (Orchidaceae). Retrieved November 7, 2013 from http://www.kew.org/plants-fungi/for-gardeners/orchids/

Koti, S., Reddy, K.R., Kakani, V.G., Zhao, D., 2005.Interactive effects of Carbon dioxide, temperatures and ultraviolet $-\mathrm{B}$ radiation on soybean (Glycine max L.) flower and pollen morphology, pollen production, germination and tube lengths. J. Exp. Biol. 56, 725-736.

Kudo, G., Harder, L.D., 2005. Floral and inflorescence effects on variation in pollen removal and seed production among six legume species. Funct. Ecol. 19, 245-254.

La Croix, I., Cribb, P.J., 1998. Flora of Zimbabwe, Orchidaceae (part 2). Flora Zambesiaca. 11(2), 238.

Medel, R., Botto-Mahan, C., Kalin-Arroyo, M., 2003. Pollinator-mediated selection on the nectar guide phenotype in the Andean monkey flower, Mimulus luteus. Ecology. 84, 1721-1732.

Miesel, J.E., Kaufmann, R.S., Pupulin, F., 2014. Orchids of Tropical America: An introduction guide. http//books.google.cm/books?isbn=0801454921.

Muller, A., Diener, S., Schnyder, S., Stutz, K., Sedivy, C., 2006. Quantitative pollen requirements of solitary bees: implications for bee conservation and the evolution of bee-flower relationships. Biol. Conserv. 130, 604-615.

Naoto, S., 1995. The pollination ecology of Bletilla striata (Orchidaceae). Ecol. Res. 10(2), 171-177.

Ndam, N., Acworth, J., Kenfack, D., Tchouto, P., Hall, J.B., 2001. Plant diversity assessment of Mount Cameroon: Survey from 1990 to 2000. Syst. Geogr. Pl. 71, 10171022.

Parra-Tabla, Vargas, M.F., 2004. Phenology and phenotypic natural selection on the flowering time of a deceitpollinated tropical orchid Myrmecophila christinae. Ann. Bot. 94, 243-250.

Payton, R.W., 1993. Ecology, Altitudinal Zonation and Conservation of Tropical Rainforest of Mount Cameroon. Final Project Report R4600, ODA; London.

Petanidou, T., Smets, E., 1996.Does temperature stress induce nectar secretion in Mediterranean plants? New Phytol. 133, 513-518.

Proctor, M., Yeo, P., Lack,A., 1996. The Pollination of Flowers. Timber Press, Portland, OR. 479p.

Saavedra, F., Inouye, D.W., Prince, M.V., 2003.Changes in flowering abundance of Delphinium nattaianum (Ranunculaceae) in response to a subalpine climate warming experiment. Global Change Biol. 9, 885-894.

Simo, M., Droissart, V., Sonke, B., Stevart, T., 2009. The Orchid Flora of the Mbam Minkom Hills (Yaounde, Cameroon). Belg. J. Bot. 142, 111-123.

Singer, B.R., Sazima, M., 2001. Flower morphology and pollination mechanism in three sympatric Goodyerinae Orchids from South Brazil. Ann. Bot. 88, 989-997.

Stevens, P. F., 2008. Angiosperm Phylogeny Website Version 9. Missouri Botanical Garden. Retrieved 26 May 2013.

Stewart, J., Campbell, B., 1996. Flora of Zambia. Timber Press Inc. Portland Oregon, USA. P548.

Tan, K.H., Nishida, R., 2000. Mutual reproductive benefits between a wild orchid Bulbophyllum patens and Bactrocerafruit flies via flora synomone. J. Chem. Ecol. 26, 533-546.

Tan, K.H., Nishida, R., 2007. Zingerone in the floral synomone of Bulbophyllum baileyi (Orchidaceae) attracts Bactrocera fruit flies during pollination. Biochem. Syst. Ecol. 26, 334-341.

Tchouto, P., 1995. The vegetation of the proposed Etinde Forest Reserve, Mount Cameroon and its conservation. M.Sc. dissertation, University of Edinburgh. 94p.

Thomson, D., 2004. Competitive interactions between the invasive European honey bee and native bumble bees. Ecology. 85, 458-470.

Waser, N.M., 1983. Competition for pollination and floral character differences among sympatric plant species: a review of evidence. In: Handbook of Experimental Pollination Biology (Eds.: Jones, C. E., Little, R. J.). Van Nostrand Reinhold, New York. pp.277-293.

Waser, N.M., Chittka, L., Price, M.V., M. Williams, N., Ollerton, J., 1996. Generalization in pollination systems, and why it matters. Ecology. 77, 1043-1060. 
Williams, N.H., 2013. The Orchid Tree: A Phylogeny of Epiphytes (mostly) on the Tree of Life. Florida Museum of Natural History. Retrieved November 7, 2013 from http://www.flmnh.ufl.edu/herbarium/orchidatol/
Wilson, E.O., 1999. Diversity of Life. W.W. Norton and Company, New York. 424p.

\section{How to cite this article:}

Essomo, S.E., Fonge, B. A., Bechem, E.E.., Tabot, P. T., Arrey, B. D., 2016. Flowering phenology and reproductive success of the Orchids of Mt Cameroon in relation to a changing environment. Int. J. Curr. Res. Biosci. Plant Biol. 3(10), 21-35. doi: http://dx.doi.org/10.20546/ijcrbp.2016.310.004 